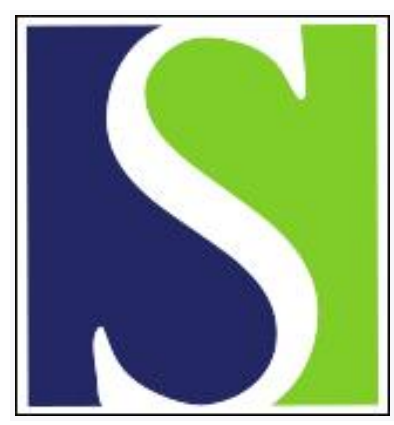

Scand J Work Environ Health 1998;24(3):236-237

https://doi.org/10.5271/sjweh.304

Issue date: Jun 1998

A possible connection between furnace dust exposure, plasma fibrinogen levels and cardiovascular disease

by Sjögren B

Refers to the following text of the Journal: 1997;23(5):334-341

The following article refers to this text: 2001;27(2):97-105

This article in PubMed: www.ncbi.nlm.nih.gov/pubmed/9710377 


\section{A possible connection between furnace dust exposure, plasma fibrinogen levels and cardiovascular disease}

In a very well-written and informative study Hobbesland and his co-workers found an increased mortality from sudden death among ferromanganese/silicomanganese furnace workers (1).

In 1955 an interesting observation was made by Rodier (2) when studying manganese-exposed Moroccan miners. The clinical signs of manganese pneumonia were first those of acute alveolar inflammation. Dyspnea was marked, the respiration was shallow, and there was gasping. The illness was altered after the 3rd day from a frank case of pneumonia to less well-defined localization and discrete pleural involvement. Death from heart failure was possible between the 5 th and the 10th day. It could also occur suddenly for patients regarded as cured. Thus it seems as if sudden death occurred in some of the patients regarded as cured.

During the last decade fibrinogen has emerged as an important risk factor for ischemic heart disease $(3,4)$. Increased concentrations of plasma fibrinogen have also been associated with myocardial infarction and sudden death among patients with angina pectoris (5).

Three deaths due to pneumonia occurred during active occupational exposure among Norwegian ferromanganese/silicomanganese furnace workers (6). Manganese pneumonia is an inflammatory disease and was associated with a marked rise in erythrocyte sedimentation rate among the Moroccan miners (2). The sedimentation rate can be influenced by several serum proteins, for example, fibrinogen, haptoglobin, immunoglobins, and ceruloplasmin (7). In other words plasma fibrinogen may be increased in this condition.

In a Belgian factory producing manganese oxides and salts, the exposed workers more often had respiratory symptoms such as cough, sputum, and acute bronchitis than a reference group did. The median exposure of manganese airborne dust was $0.97 \mathrm{mg} / \mathrm{m}^{3}$. The exposed group also had an increased prevalence of chronic bronchitis, but the difference was not significant (8). It has recently been shown that persons with chronic bronchitis have an increased risk for coronary disease and coronary deaths (9).

The mentioned manganese-exposed Belgian workers had decreased lung function for several spirometric parameters, for example, forced vital capacity (FVC), forced expiratory volume in 1 second $\left(\mathrm{FEV}_{1.0}\right)$, and peak expiratory flow (PEF) (8). A relationship between decreased lung function (VC and $\mathrm{FEV}_{1.0}$ ) and increased levels of fibrinogen was found in a study of 788 Swedish men (10). Several studies have observed a relationship between a decreased lung function [expressed as VC (11), $\mathrm{FEV}_{1.0}$ (12), or PEF (13)] and ischemic heart disease.

A general hypothesis regarding inhaled particle exposure and the occurrence of IHD can be expressed in the following way. Long-term inhalation of particles retained in the lungs will create low-grade inflammation in association with an increase in plasma fibrinogen. The high levels of fibrinogen increase the likelihood for blood clotting and thereby the risk for myocardial infarction, ischemic heart disease, and possibly sudden death $(14,15)$. This hypothesis would be supported if furnace workers have a higher concentration of plasma fibrinogen than nonfurnace workers with control for other possible confounders (eg, smoking) (16).

\section{References}

1. Hobbesland $\AA$, Kjuus H, Thelle DS. Mortality from cardiovascular diseases and sudden death in ferroalloy plants. Scand JWork Environ Health 1997;23(5):334-41.

2. Rodier J. Manganese poisoning in Moroccan miners. Br J Ind Med 1955;12:21-35.

3. Meade TW, Mellows S, Brozovic M, Miller GJ, Chakrabarti RR, North WRS, et al. Haemostatic function and ischaemic heart disease: principle results of the Nortwick Park heart study. Lancet 1986;2: $533-7$.

4. Yarnell JWG, Baker IA, Sweetnam PM, Bainton D, O'Brien JR, Whitehead PJ, et al. Fibrinogen, viscosity, and white blood cell count are major risk factors for ischemic heart disease. Circulation 1991;83:836-44.

5. Thompson SG, KienastJ, Pyke SDM, Haverkate F, Van de Loo JCW. Hemostatic factors and the risk of myocardial infarction or sudden death in patients with angina pectoris. $\mathrm{N}$ Engl J Med 1995;332:635-41.

6. Hobbesland $\AA$, Kjuus $\mathrm{H}$, Thelle DS. Mortality from nonmalignant respiratory diseases among male workers in Norwegian ferroalloy plants. Scand J Work Environ Health 1997;23(5):342-50.

7. Arnold WJ, Ike RW. Specialized procedures in the management of patients with rheumatic diseases. In: Wyngaarden JB, Smith LH, Bennet JC, editors. Cecil textbook of medicine. Philadelphia (PA): WB Saunders Company, 1992:1505.

8. Roels H, Lauwerys R, Buchet J-P, Genet P, Jawad Sarhan M, Hanotiau I, et al. Epidemiological survey among workers exposed to manganese: effects on lung, central nervous system, and some biological indices. Am J Ind Med 1987;11:307-27.

9. Jousilahti P, Vartiainen E, Tuomilehto J, Puska P. Symptoms of chronic bronchitis and the risk of coronary disease. Lancet 1996;348:567-72.

10. Korsan-Bengtsen $\mathrm{K}$, Wilhelmsen L, Tibblin G. Blood coagulation and fibrinolysis in a random sample of 788 men 54 years old, II: relations of the variables to "risk factors" for myocardial 
infarction. Thrombos Diathes Haemorrh 1972;28:99--108.

11. Kannel WB, Wilson P, Blair SN. Epidemiological assessment of the role of physical activity and fitness in development of cardiovascular disease. Am Heart J 1985;109:87685.

12. Hole DJ, Watt GCM, Davey-Smith G, Hart CL, Gillis CR, Hawthorne VM. Impaired lung function and mortality risk in men and women: findings form the Renfrew and Paisley prospective population study. BMJ 1996;313:711-5.

13. Persson C, Bengtsson C, Lapidus L, Rybo E, Thiringer G, Wedel H Peak expiratory flow and risk of cardiovascular disease and death. AmJ Epidemiol 1986;124:942-8.

14. Seaton A, MacNee W, Donaldson K, Godden D. Particulate air pollu- tion and acute health effects. Lancet 1995;345:176-8.

15. Sjögren B. Occupational exposure to dust: inflammation and ischaemic heart disease. Occup Environ Med 1997;54:466-9.

16. Rosengren A, Wilhelmsen L, Welin L, Tsipogianni A, Teger-Nilsson A-C, Wedel $\mathrm{H}$. Social influences and cardiovascular risk factors as determinants of plasma fibrinogen concentration in a general population sample of middle age men. BMJ 1990;300:634 -8.

Bengt Sjögren, MD

Wolf Project

Department for Work and Health

National Institute for Working Life

S-171 84 Solna, Sweden 